\title{
High-Efficiency Gold Recovery Using Cucurbit[6]uril
}

Huang Wu,${ }^{\dagger}$ Leighton O. Jones,${ }^{\dagger}$ Yu Wang, ${ }^{\dagger}$ Dengke Shen, ${ }^{\dagger}$ Zhichang Liu,${ }^{\perp}$ Long Zhang, ${ }^{\dagger}$ Kang Cai, ${ }^{\dagger}$ Yang Jiao, ${ }^{\dagger}$ Charlotte L. Stern,${ }^{\dagger}$ George C. Schatz ${ }^{\dagger}$ and J. Fraser Stoddart ${ }^{*}, \dagger, \nabla, \|$

'Department of Chemistry, Northwestern University, 2145 Sheridan Road, Evanston, Illinois 60208, United States

${ }^{+}$School of Science, Westlake University, 18 Shilongshan Road, Hangzhou 310024, China

${ }^{\square}$ School of Chemistry, University of New South Wales, Sydney, NSW 2052, Australia

"Institute for Molecular Design and Synthesis, Tianjin University, 92 Weijin Road, Nankai District, Tianjin 300072, P.R. China

*E-mail: stoddart@northwestern.edu

\section{Supporting Information}

\section{Table of Contents}

Section A. Materials / Instrumentation ..................................................

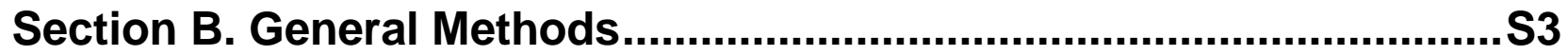

Section C. Crystallographic Characterization .........................................S4

Section D. Powder X-Ray Diffraction Analysis .....................................S9

Section E. Fourier-Transform Infrared/Thermogravimetric Analysis .S10

Section F. Density Function Theory Calculations ................................. 11

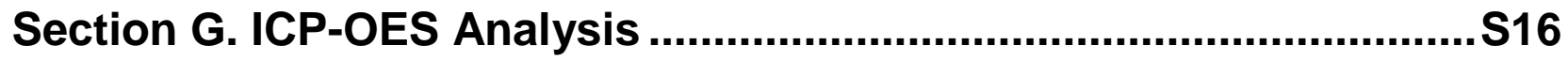

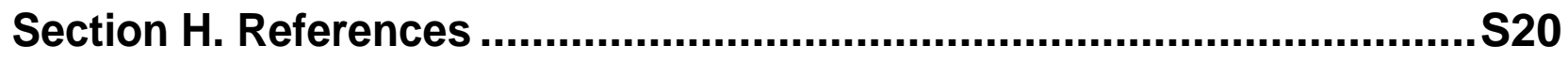




\section{Section A. Materials / Instrumentation}

\section{(1) Materials}

All gold salt $\left(\mathrm{HAuCl}_{4}, \mathrm{KAuCl}_{4}, \mathrm{HAuBr}_{4}, \mathrm{KAuBr}\right.$ ), $\mathrm{HCl}$ (wt 37\%) aqueous solutions, $\mathrm{HBr}$ (wt 47-49\%) aqueous solutions and $\mathrm{H}_{2} \mathrm{O}_{2}$ (wt 30\%) aqueous solutions were purchased from commercial suppliers and used without further purification unless stated otherwise. The cucurbit[6] uril was synthesized according to the previous literature with some modifications ${ }^{1}$. High purity water was generated by a Milli-Q.

\section{(2) Inductively Coupled Plasma Optical Emission Spectrometry Analysis}

Inductively coupled plasma optical emission spectrometry (ICP-OES) was performed on a thermo iCap7600 ICP-OES (Thermo Fisher Scientific, Waltham, MA, USA) operating in radial view and equipped with a CETAC 520 autosampler (Omaha, NE, USA). The samples were filtered through a $0.45-\mu \mathrm{m}$ filter. The filtrates were then diluted with ultrapure $\mathrm{H}_{2} \mathrm{O}$ and analyzed for the concentration of $\mathrm{Au}$ in comparison with standard solutions. Each sample was recorded using $5 \mathrm{sec}$ visible exposure and $15 \mathrm{sec}$ UV exposure time. Each sample was measured repeatedly for 3 times. The wavelengths selected for the analyses of the concentration of Au were 208.209, 242.795, and $267.595 \mathrm{~nm}$.

\section{(3) Powder X-ray Diffraction Analysis}

Powder X-ray diffraction (PXRD) analyses were carried out on a STOE-STADI MP powder diffractometer equipped with an asymmetric curved Germanium monochromator ( $\mathrm{Cu}-\mathrm{K} \alpha 1$ radiation, $\lambda=1.54056 \AA$ ) and a one-dimension silicon strip detector (MYTHEN2 1K from DECTRIS). Samples for structural analysis were measured at room temperature in transmission geometry. The simulated PXRD patterns were calculated using the Mercury software 4.3.0.

\section{(4) Thermogravimetric Analysis}

Thermogravimetric analysis (TGA) experiments were performed on a Mettler Toledo TGA / DSC1 Stare System (Schwerzenbach, Switzerland) interfaced with a PC using Stare software. Samples were placed in an $\mathrm{Al}_{2} \mathrm{O}_{3}$ crucible and heated at a rate of $10 \mathrm{~K} \mathrm{~min}^{-1}$ from 35 to $800{ }^{\circ} \mathrm{C}$ under a helium atmosphere.

\section{(5) Fourier-Transform Infrared Spectroscopy}

Fourier-transform infrared (FT-IR) spectroscopy was performed on a Nexus 870 spectrometer (Thermo Nicolet) in the mode of attenuated total reflection (ATR) with the range from 4000 to 600 $\mathrm{cm}^{-1}$ and at a resolution of $0.125 \mathrm{~cm}^{-1}$. 


\section{Section B. General Methods}

\section{(1) Co-precipitation experiments of $\mathrm{CB}[6]$ with $\mathrm{MAuX}_{4}(\mathrm{M}=\mathrm{H} / \mathrm{K}, \mathrm{X}=\mathrm{Cl} / \mathrm{Br})$}

Aqueous stock solutions of $\mathrm{HAuCl}_{4}, \mathrm{KAuCl}_{4}, \mathrm{HAuBr}_{4}, \mathrm{KAuBr}_{4}$ were prepared by dissolving directly the corresponding commercially available salts in high purity $\mathrm{H}_{2} \mathrm{O}$, while aqueous solutions of $\mathrm{CB}[6]$ were prepared by dissolving the $\mathrm{CB}[6]$ powder with different concentrations of $\mathrm{HCl}$ or $\mathrm{HBr}$. When $\mathrm{CB}[6](8 \mathrm{mM})$ in an aqueous $\mathrm{HCl}$ or $\mathrm{HBr}$ solution was added to a $\mathrm{MAuX}_{4}(20$ $\mathrm{mM}, \mathrm{M}=\mathrm{H} / \mathrm{K}, \mathrm{X}=\mathrm{Cl} / \mathrm{Br}$ ) aqueous solution, yellow and brown co-precipitates were formed immediately. The yellow and brown solids were isolated by filtration and air-dried. The concentrations of $\left[\mathrm{AuX}_{4}\right]^{-}(\mathrm{M}=\mathrm{Cl} / \mathrm{Br})$ remaining in the filtrates were analyzed by ICP-OES analysis and compared with standard solutions (Figure S13). The gold-recovery efficiencies from the co-precipitation experiments were calculated based on the initial and residue concentrations of $\left.[\mathrm{AuX}]_{4}\right]^{-}$in the aqueous solution.

\section{(2) Process for gold recovery from gold-bearing materials}

(a) A yellow gold-bearing alloy wire, composed of $58 \%$ wt $\mathrm{Au}, 42 \%$ wt of $\mathrm{Cu}, \mathrm{Zn}$ and $\mathrm{Ag}$, was employed (Figure 8 ) as gold-bearing scrap in a laboratory-scale gold recovery experiment. The yellow gold-bearing alloy $\left(30 \mathrm{mg}\right.$ ) was first of all etched by a mixture of $\mathrm{HCl}$ and $\mathrm{H}_{2} \mathrm{O}_{2}$. Subsequently, the concentration of acid in the resulting gold-bearing solution was adjusted to $\sim 2$ $M$ with high purity $\mathrm{H}_{2} \mathrm{O}$, and insoluble $\mathrm{AgCl}$ impurities were removed by filtration. Upon the addition of an aqueous solution of $\mathrm{CB}[6](40 \mathrm{mM})$ to the residual filtrate, the yellow co-precipitate of $\mathbf{C B}[6] \cdot \mathbf{H A u C l}_{4}$, which formed immediately, was separated from other metals by filtration. Finally, the $\mathbf{C B}[\mathbf{6}] \cdot \mathbf{H A u C l} 4$ co-precipitation was dispersed in aqueous $\mathrm{HCl}(2 \mathrm{M})$ solution and then reduced with $\mathrm{N}_{2} \mathrm{H}_{4} \cdot \mathrm{H}_{2} \mathrm{O}(1.0 \mathrm{~mL})$. The resulting gold was recovered by filtration and washed with aqueous $\mathrm{HCl}(2 \mathrm{M})$ solution to removed $\mathrm{CB}[6]$. The $\mathrm{CB}[6]$ in filtrate can be recycled after recrystallization. The ICP-OES analysis revealed (Table S13-14) that $99.8 \%$ of gold in raw material was recovered and its purity is $98.1 \%$. According to this gold-recovery procedure, approximately $7.1 \mathrm{mg}$ of gold was recovered (90.0\% yield) from $13.6 \mathrm{mg}$ of gold-bearing $(58 \% \mathrm{wt})$ alloy wire. This yield is slightly lower than the gold-recovery efficiency of $99.8 \%$ obtained from ICP-OES analysis. The difference may arise from the loss of gold during filtering and washing procedures

(b) In order to test the validity of employing $\mathrm{CB}[6]$ to recover gold from a mixture with small amounts of gold, a considerable amount of additional $\mathrm{Cu}$ and $\mathrm{Zn}$ were added to the leaching solution of 58\% wt Au alloy. The concentration of gold in two resulting mixture were 5.5\% wt Au and $2.6 \% \mathrm{wt} \mathrm{Au}$, respectively. Upon the addition of an aqueous solution of $\mathrm{CB}$ [6] (40 $\mathrm{mM})$ to those solution, a mount of co-precipitate occurred. ICP-OES Analyses revealed (Table S15) that 98.5 and $97.4 \%$ of gold in the $5.5 \% \mathrm{wt}$ and $2.6 \% \mathrm{wt}$ gold-bearing mixture were recovered, respectively. 


\section{Section C. Crystallographic Characterization}

The crystals for all the five adducts-namely, $\mathrm{CB}[\mathbf{6}] \cdot \mathrm{HAuCl}_{4}, \mathbf{C B}[\mathbf{6}] \cdot \mathrm{KAuCl}_{4}, \mathbf{C B}[\mathbf{6}] \cdot \mathrm{HAuBr}_{4}$,

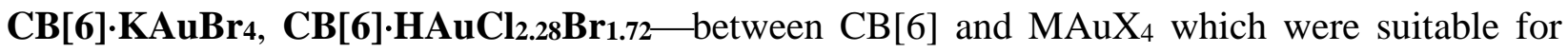
single crystal X-ray crystallography, were obtained by slow liquid-liquid diffusion. The detailed procedures were executed as follows. The stock aqueous solutions of $\mathrm{HAuCl}_{4}$ and $\mathrm{KAuCl}_{4}(20 \mathrm{mM}$, $100 \mu \mathrm{L})$ were layered carefully upon an aqueous CB[6] (10 mM, $200 \mu \mathrm{L})$ solution with $3 \mathrm{M} \mathrm{HCl}$ in 1-mL tubes. High quality yellow co-crystals of $\mathbf{C B}[\mathbf{6}] \cdot \mathbf{H A u C l}_{4}$ and $\mathbf{C B}[\mathbf{6}] \cdot \mathrm{KAuCl}_{4}$ were obtained after about $12 \mathrm{~h}$. Using a similar procedure, aqueous stock solutions of $\mathrm{HAuBr}_{4}$ and $\mathrm{KAuBr}_{4}(20 \mathrm{mM}, 100 \mu \mathrm{L})$ were layered carefully upon the aqueous $\mathrm{CB}[6](8 \mathrm{mM}, 250 \mu \mathrm{L})$ solution with $3.5 \mathrm{M} \mathrm{HBr}$ in 1-mL tubes. High quality brown co-crystals of $\mathbf{C B}[\mathbf{6}] \cdot \mathbf{H A u B r} 4$ and CB[6]-KAuBr 4 were obtained after about 1 day. The aqueous stock solution of $\mathrm{HAuBr}_{4}(20 \mathrm{mM}$, $100 \mu \mathrm{L})$, which was carefully layered onto the aqueous CB[6] (10 mM, $200 \mu \mathrm{L})$ solution with $3 \mathrm{M}$ $\mathrm{HCl}$ in 1-mL tubes, produced high quality brown co-crystals of $\mathbf{C B}[\mathbf{6}] \cdot \mathbf{H A u C l} \mathbf{C l}_{2.28} \mathbf{B r} \mathbf{1}_{\mathbf{2}}$ after about $12 \mathrm{~h}$.

Suitable crystals were selected and mounted on a MITIGEN holder with Paratone oil on an XtaLAB Synergy, Single source at offset/far, HyPix diffractometer. The crystals were kept at $\sim 100$ $\mathrm{K}$ during the data collection. Using Olex $2,{ }^{2}$ the structures were solved with the ShelXT ${ }^{3}$ structure solution program using Intrinsic Phasing and refined with the $\mathrm{XL}^{4}$ refinement package employing Least Squares Minimization. Crystallographic images were produced using Mercury 4.3.0. Distances and angles were measured employing Mercury 4.3.0. All the hydrogen bonds distances have been defined as the distances between the appropriate carbon atoms to heteroatoms or other carbon atoms supporting hydrogen bonds. Figures 5-7 and Figures S1-S3 show the single-crystal packing superstructures of $\mathrm{CB}[6] \cdot \mathrm{HAuCl}_{4}, \mathrm{CB}[6] \cdot \mathrm{KAuCl}_{4}, \mathrm{CB}[6] \cdot \mathrm{HAuBr}_{4}, \mathrm{CB}[6] \cdot \mathrm{KAuBr}_{4}$, and CB[6].HAuCl2.28Br1.72, respectively. Table S1 reports the crystallographic data of all five crystalline adducts.

All crystallographic data are available free of charge from the Cambridge Crystallographic Data Centre (CCDC) via www.ccdc.cam.ac.uk/data_request/cif.

\section{(1) $\mathrm{CB}[6] \cdot \mathrm{KAuCl}_{4}$}

(a) Refinement and solvent treatment details. No special refinement was necessary in the case of solving the solid-state superstructure of $\mathbf{C B}[\mathbf{6}] \cdot \mathbf{K A u C l} 4$. The solvent masking procedure, as implemented in Olex2, was used to remove the electronic contributions of solvent molecules from the refinement. As the exact solvent content is not known, only the atoms used in the refinement model are reported in the formula here. Total solvent accessible volume / cell $=285.0 \AA^{3}[8.5 \%]$ and total electron count $/$ cell $=51.8$. The solid-state (super)structure of $\mathbf{C B}[\mathbf{6}] \cdot \mathbf{K A u C l} 4$ is illustrated in Figure S1. 
(a)

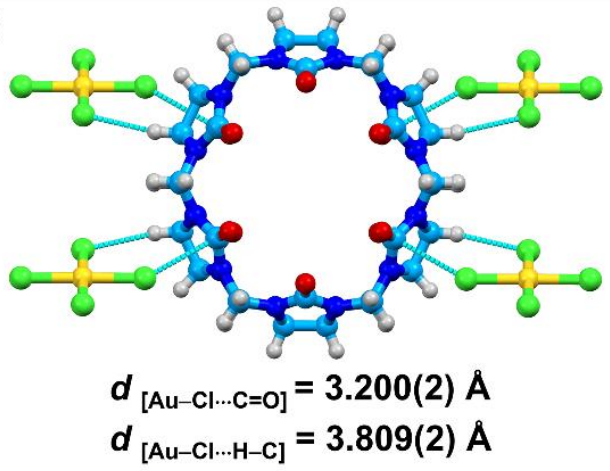

(c)

\section{Front View}

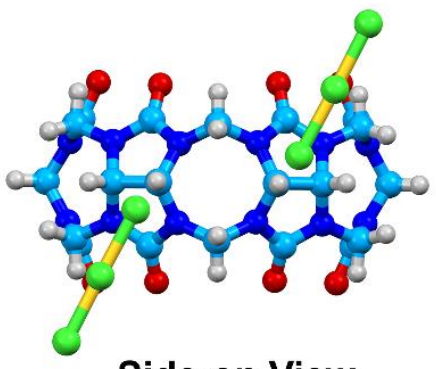

(b)

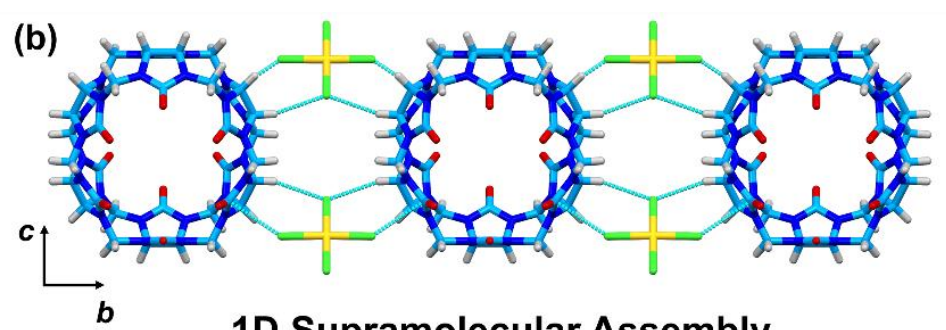

1D Supramolecular Assembly

(d)

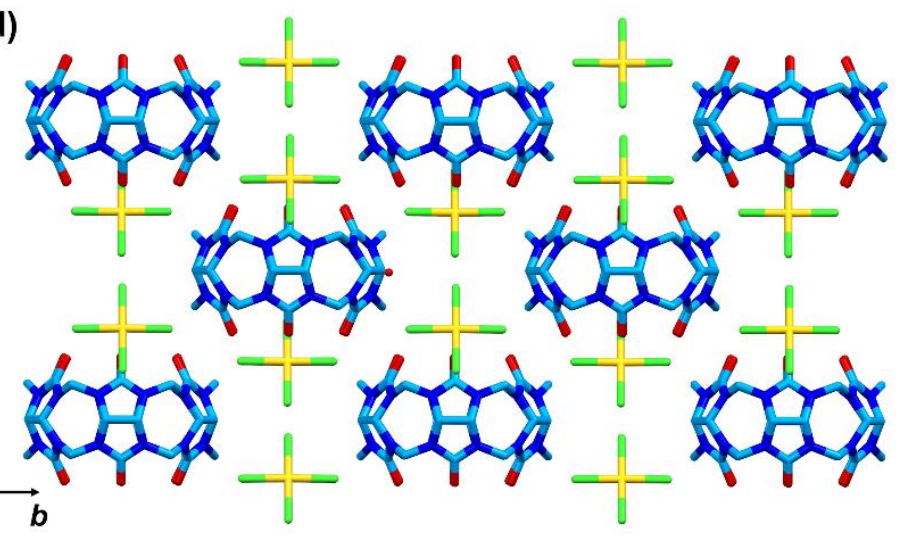

Figure S1. Solid-state superstructures of the adduct formed between $\mathrm{CB}[6]$ and $\mathrm{KAuCl}_{4}$. (a, c) Ball-and-stick representations showing different views of every $\mathrm{CB}[6]$ interacting with four $\left[\mathrm{AuCl}_{4}\right]^{-}$anions through $[\mathrm{Au}-\mathrm{Cl} \cdots \mathrm{H}-\mathrm{C}]$ hydrogen bonding and ion-dipole interactions. (b) The supramolecular assembly of the one-dimensional nanostructure, extending along the $b$-axis in which adjacent $\mathrm{CB}[6]$ molecules are connected by two parallelly aligned $\left[\mathrm{AuCl}_{4}\right]^{-}$anions, is portrayed. (d) The solid-state superstructure of $\mathbf{C B}[\mathbf{6}] \cdot \mathbf{H A u C l} \mathbf{H}_{\mathbf{4}}$ is made up of the parallelly aligned one-dimensional supramolecular assembly illustrated in (b). The $\mathrm{H}_{2} \mathrm{O}$ molecules are omitted for the sake of clarity. $\mathrm{H}$ gray, $\mathrm{C}$ pale blue, $\mathrm{N}$ blue, $\mathrm{O}$ red, $\mathrm{Cl}$ green, $\mathrm{Au}$ yellow.

\section{(2) $\mathrm{CB}[6] \cdot \mathrm{KAuBr} 4$.}

(a) Refinement details. The crystal of $\mathbf{C B}[\mathbf{6}] \cdot \mathbf{K A u B r} 4$ was found to be non-merohedrally twinned. The orientation matrices for the two components were identified using the program CrysAlisPro (Rigaku Oxford Diffraction, 2019). The exact twin matrix, identified by the integration program, was found to be $(-1.0008-0.0002-0.0005 /-0.0007-1.0006-0.0034 / 0.89100 .05380 .9990)$. The second domain is rotated from first domain by $180^{\circ}$ about the reciprocal lattice $c$ axis. An hklf5 file was used in all refinements. The twin fraction refined to a value of 0.315(3). Distance restraints were imposed on the $\mathrm{C}-\mathrm{N}$ bonds. The enhanced rigid-bond restraint (SHELX keyword RIGU) was applied globally. ${ }^{5}$ Restraints on similar amplitudes separated by less than $1.7 \AA$ were also imposed globally. 
(b) Solvent treatment details. In the case of the crystal of $\mathbf{C B}[\mathbf{6}] \cdot \mathbf{K A u B r} 4$, the disordered solvent molecules could not be modeled adequately. The bypass procedure in Platon was used to remove the electronic contribution from these solvents. The total potential solvent accessible void volume was $573 \AA^{3}$ and the electron count / cell = 152.0. As the exact solvent content is not known, the reported formula reflects only the atoms used in the refinement. The solid-state (super)structure of CB[6]·KAuBr 4 is illustrated in Figure S2.
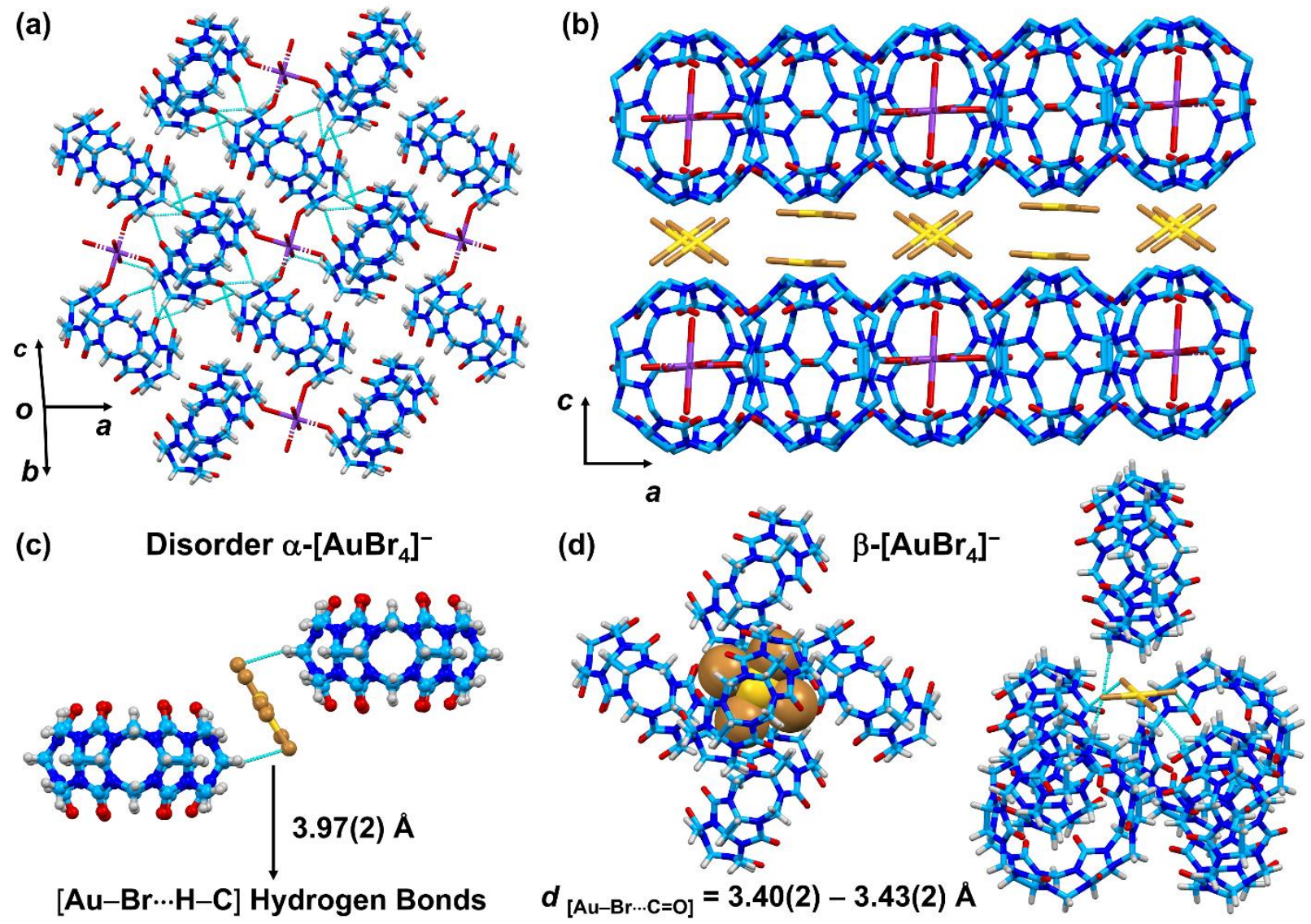

Figure S2. Single-crystal superstructures of the adduct formed between $\mathrm{CB}[6]$ and $\mathrm{KAuBr}_{4}$. (a) The supramolecular assembly of the two-dimensional nanostructure through multiple ion-dipole interactions between $\mathrm{K}^{+}$and $\mathrm{CB}[6]$ molecules, as well as hydrogen bonding between two adjacent $\mathrm{CB}[6]$ molecules. (b) Solid-state superstructure of $\mathbf{C B}[\mathbf{6}] \cdot \mathbf{K A u B r} 4$, in which two kinds of $\left[\mathrm{AuBr}_{4}\right]^{-}$ $-\alpha-\left[\mathrm{AuBr}_{4}\right]^{-}$and $\beta-\left[\mathrm{AuBr}_{4}\right]^{-}$-are accommodated in the lattice space between the twodimensional supramolecular assembly illustrated in (a). (c) Ball-and-stick representation showing that every $\alpha-\left[\mathrm{AuBr}_{4}\right]^{-}$interacts with two $\mathrm{CB}[6]$ molecules through $[\mathrm{Au}-\mathrm{Br} \cdots \mathrm{H}-\mathrm{C}]$ hydrogen bonding, and is accompanied with disordered over two position with 50:50 occupancies. (d) The $\beta-\left[\mathrm{AuBr}_{4}\right]^{-}$interacts with five $\mathrm{CB}[6]$ molecules through $[\mathrm{Au}-\mathrm{Br} \cdots \mathrm{H}-\mathrm{C}]$ hydrogen bonding and ion-dipole interactions. $\mathrm{H}$ gray, $\mathrm{C}$ pale blue, $\mathrm{N}$ blue, $\mathrm{O}$ red, $\mathrm{Br}$ brown, $\mathrm{K}$ purple, Au yellow. 


\section{(3) $\mathrm{CB}[6] \cdot \mathrm{HAuCl}_{2.28} \mathrm{Br}_{1.72}$}

(a) Refinement and solvent treatment details. In the crystal of $\mathbf{C B}[\mathbf{6}] \cdot \mathbf{H A u C l} \mathbf{l}_{2.28} \mathbf{B r} \mathbf{1 . 7 2}$, chlorine and bromine atoms were disordered individually. The solvent masking procedure, as implemented in Olex2, was used to remove the electronic contribution of the solvent molecules from the refinement. As the exact solvent content is not known, only the atoms used in the refinement model are reported in the formula here. Total solvent accessible volume / cell $=283.8 \AA^{3}[8.4 \%]$ and total electron count $/$ cell $=55.6$ The solid-state (super)structure of $\mathbf{C B}[\mathbf{6}] \cdot \mathbf{H A u C l} 2.28 \mathbf{B r} 1.72$ is illustrated in Figure S3.

(a)

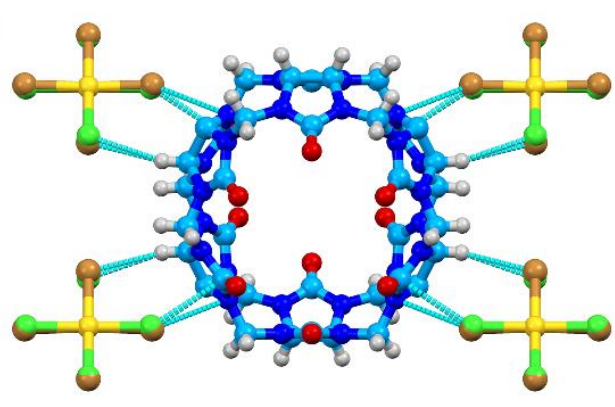

Front View

(c)

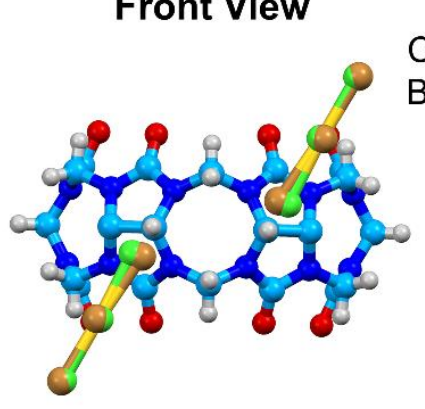

Side-on View (b)

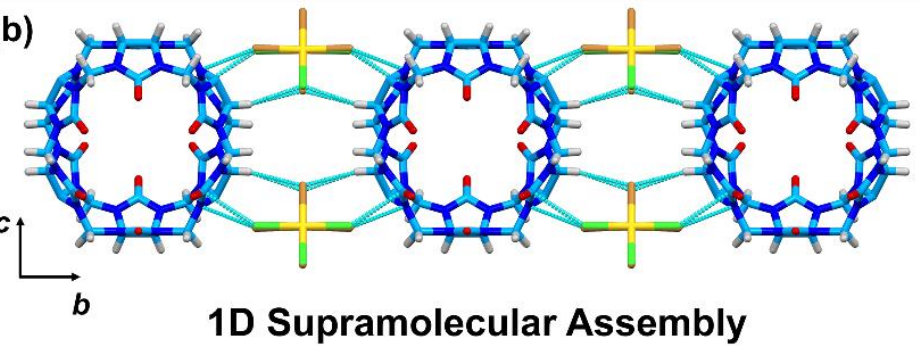

(d)

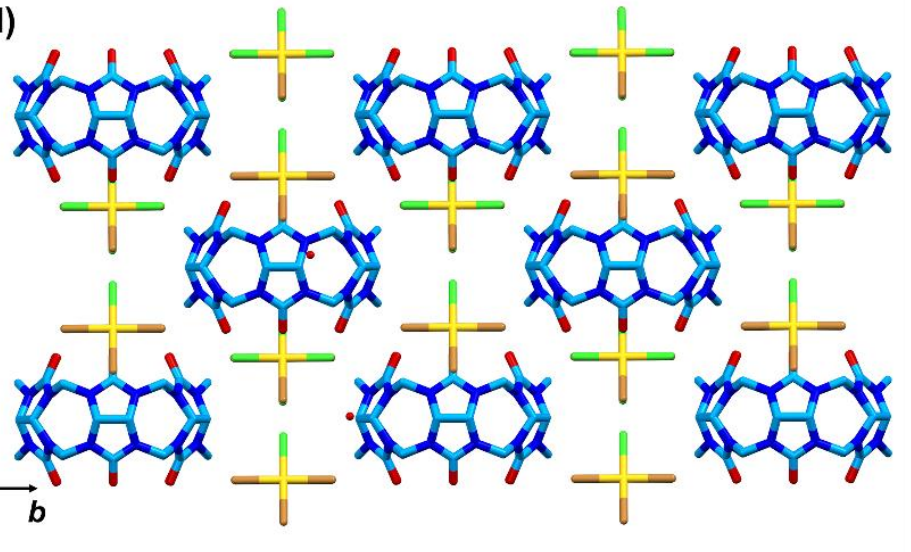

Figure S3. Single-crystal superstructure of the adduct formed between $\mathrm{CB}[6]$ and $\mathrm{HAuCl}_{2.28} \mathrm{Br}_{1.72}$. (a, c) Ball-and-stick representations showing the different views of how every $\mathrm{CB}[6]$ interacts with four $\left[\mathrm{Au} \mathrm{Cl}_{2.28} \mathrm{Br}_{1.72}\right]^{-}$through $[\mathrm{Au}-\mathrm{X} \cdots \mathrm{H}-\mathrm{C}](\mathrm{X}=\mathrm{Cl} / \mathrm{Br})$ hydrogen bonding and ion-dipole interactions. (b) The supramolecular assembly of the one-dimensional nanostructure extending along the $b$-axis, in which adjacent $\mathrm{CB}[6]$ molecules are connected by two parallelly aligned $\left[\mathrm{AuCl}_{2.28} \mathrm{Br}_{1.72}\right]^{-}$anions. (d) Solid-state superstructure of $\mathbf{C B}[\mathbf{6}] \cdot \mathbf{H A u C l} 2.28 \mathbf{B r} 1.72$, which is made up of the parallelly aligned one-dimensional supramolecular assembly illustrated in (b). $\mathrm{The}_{2} \mathrm{O}$ molecules are omitted for the sake of clarity. $\mathrm{H}$ gray, $\mathrm{C}$ pale blue, $\mathrm{N}$ blue, $\mathrm{O}$ red, $\mathrm{Cl}$ green, $\mathrm{Br}$ brown, Au yellow. 
Table S1. Crystallographic Data for Five Complexes Between $\mathrm{CB}[6]$ and $\mathrm{MAuX}_{4}(\mathrm{M}=\mathrm{H} /$ $\mathrm{K}, \mathrm{X}=\mathrm{Cl} / \mathrm{Br})$

\begin{tabular}{|c|c|c|c|c|c|}
\hline Complex & $\mathrm{CB}[6] \cdot \mathrm{HAuCl}_{4}$ & $\mathrm{CB}[6] \cdot \mathrm{HAuBr}_{4}$ & $\mathrm{CB}[6] \cdot \mathrm{KAuCl}_{4}$ & $\mathrm{CB}[6] \cdot \mathrm{KAuBr}_{4}$ & $\mathrm{CB}[6] \cdot \mathrm{HAuCl}_{2.28} \mathrm{Br}_{1.72}$ \\
\hline Empirical & $\mathrm{C}_{18} \mathrm{H}_{32} \mathrm{Au}$ & $\mathrm{C}_{72} \mathrm{H}_{74} \mathrm{Au}_{2}$ & $\mathrm{C}_{36} \mathrm{H}_{64} \mathrm{Au}_{2}$ & $\mathrm{C}_{36} \mathrm{H}_{36} \mathrm{Au}$ & $\mathrm{C}_{36} \mathrm{H}_{64} \mathrm{Au}_{2}$ \\
\hline formula & $\mathrm{Cl}_{4} \mathrm{~N}_{12} \mathrm{O}_{13}$ & $\mathrm{Br}_{8} \mathrm{~N}_{48} \mathrm{O}_{25}$ & $\mathrm{Cl}_{8} \mathrm{~N}_{24} \mathrm{O}_{26}$ & $\mathrm{Br}_{4} \mathrm{~K}_{0.5} \mathrm{~N}_{24} \mathrm{O}_{12.5}$ & $\mathrm{Br}_{3.43} \mathrm{Cl}_{4.57} \mathrm{~N}_{24} \mathrm{O}_{26}$ \\
\hline $\begin{array}{c}\text { Formula } \\
\text { weight }\end{array}$ & 963.32 & 3045.00 & 1926.64 & 1541.04 & 2079.14 \\
\hline$T / \mathrm{K}$ & $101.00(2)$ & $100.00(10)$ & $100.01(10)$ & $100.01(12)$ & $100.00(10)$ \\
\hline Crystal system & monoclinic & tetragonal & monoclinic & triclinic & monoclinic \\
\hline Space group & $C 2 / m$ & $I \overline{4} 2 d$ & $C 2 / m$ & $P \overline{1}$ & $C 2 / m$ \\
\hline$a / \AA$ & $16.1427(4)$ & $14.4358(2)$ & $16.1569(3)$ & $14.3299(14)$ & $16.2232(3)$ \\
\hline$b / \AA$ & $16.3995(4)$ & $14.4358(2)$ & $16.4325(3)$ & $14.3772(11)$ & $16.5456(3)$ \\
\hline$c / \AA$ & $12.6960(3)$ & $58.4604(11)$ & $12.6862(3)$ & $15.9853(12)$ & $12.6850(2)$ \\
\hline$\alpha /^{\circ}$ & 90 & 90 & 90 & $66.228(7)$ & 90 \\
\hline$\beta /^{\circ}$ & $93.083(2)$ & 90 & $93.273(2)$ & $88.468(7)$ & $93.6000(16)$ \\
\hline$\gamma /{ }^{\circ}$ & 90 & 90 & 90 & $89.781(7)$ & 90 \\
\hline$V / \AA^{3}$ & $3356.18(14)$ & $12182.7(4)$ & $3362.67(12)$ & $3012.8(5)$ & $3398.25(10)$ \\
\hline$Z$ & 4 & 4 & 2 & 2 & 2 \\
\hline$\rho_{\text {calcd }} / \mathrm{g} \mathrm{cm}^{-3}$ & 1.906 & 1.660 & 1.903 & 1.699 & 2.032 \\
\hline$\mu / \mathrm{mm}^{-1}$ & 4.779 & 5.110 & 4.770 & 5.200 & 6.601 \\
\hline$F(000)$ & 1900 & 5920 & 1900 & 1497 & 2023 \\
\hline $\begin{array}{l}\text { goodness-of- } \\
\text { fit on } F^{2}\end{array}$ & 1.075 & 1.016 & 1.051 & 1.410 & 1.080 \\
\hline$R_{l}[I>2 \sigma(I)]$ & 0.0244 & 0.0901 & 0.0334 & 0.1468 & 0.0363 \\
\hline$w R_{2}$ [all data] & 0.0634 & 0.2663 & 0.0896 & 0.4354 & 0.0882 \\
\hline CCDC No. & 1983307 & 1983308 & 1983307 & 1983309 & 1983310 \\
\hline
\end{tabular}




\section{Section D. Powder X-Ray Diffraction Analysis}
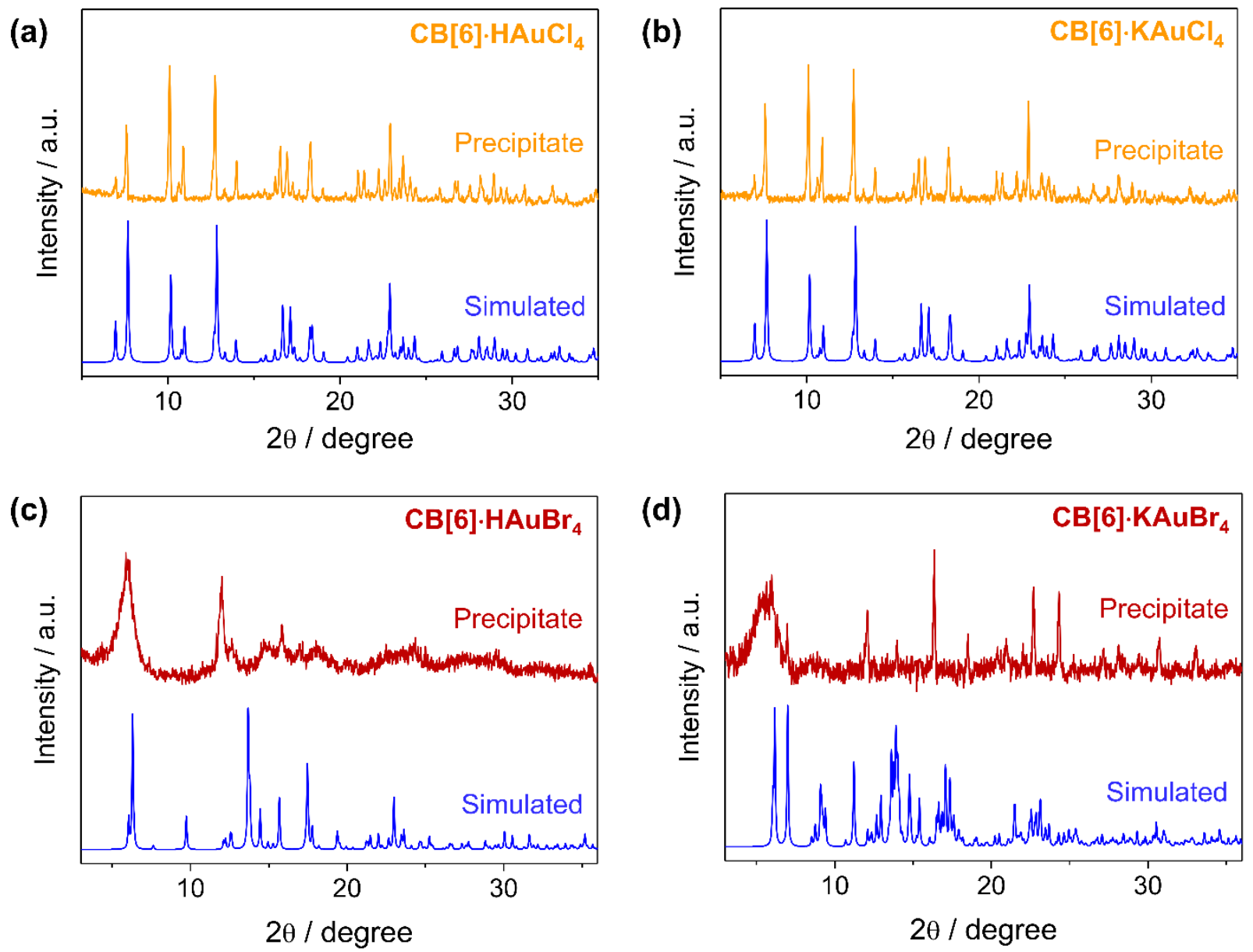

Figure S4. Powder X-ray diffraction patterns of the co-precipitates (a) $\mathbf{C B}[\mathbf{6}] \cdot \mathbf{H A u C l} 4$, (b) $\mathrm{CB}[6] \cdot \mathrm{KAuCl}_{4}$, (c) $\mathrm{CB}[6] \cdot \mathbf{H A u B r}$, (d) $\mathrm{CB}[6] \cdot \mathrm{KAuBr}_{4}$, compared with simulated patterns derived from their X-ray crystallographic data.

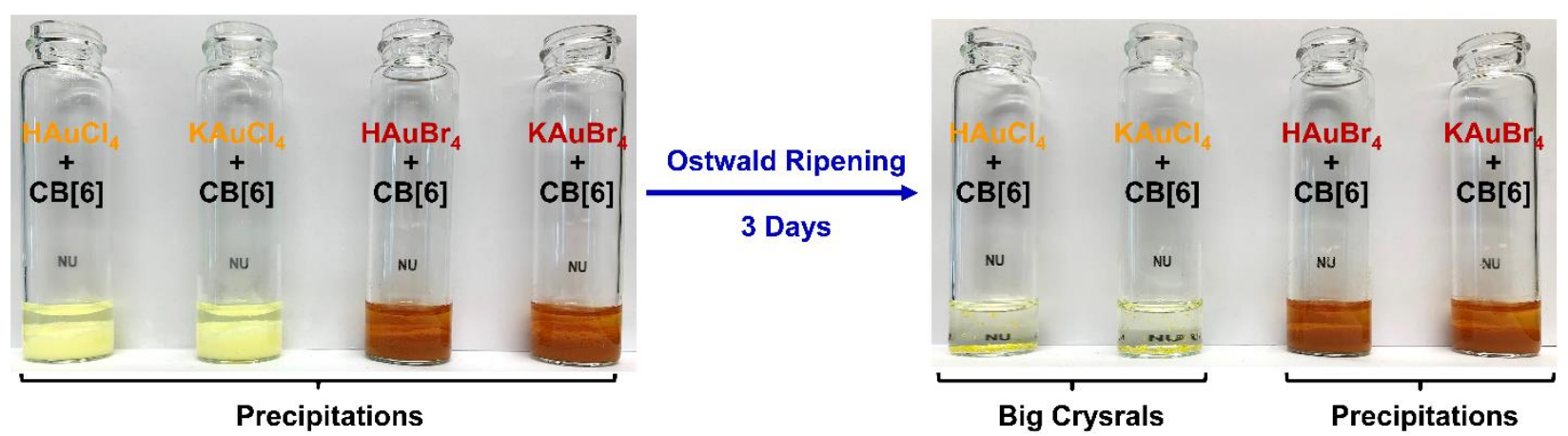

Figure S5. The photographic images of the Ostwald ripening process for the four co-precipitates $\mathbf{C B}[6] \cdot \mathbf{M A u X}_{4}(\mathrm{M}=\mathrm{H} / \mathrm{K}, \mathrm{X}=\mathrm{Cl} / \mathrm{Br})$. It reveals that the co-precipitates of $\mathbf{C B}[\mathbf{6}] \cdot \mathbf{M A u C l}_{4}$ change from co-precipitates to big crystals, respectively, while the co-precipitates of CB[6]·MAuBr4 do not exhibit much change at all. 

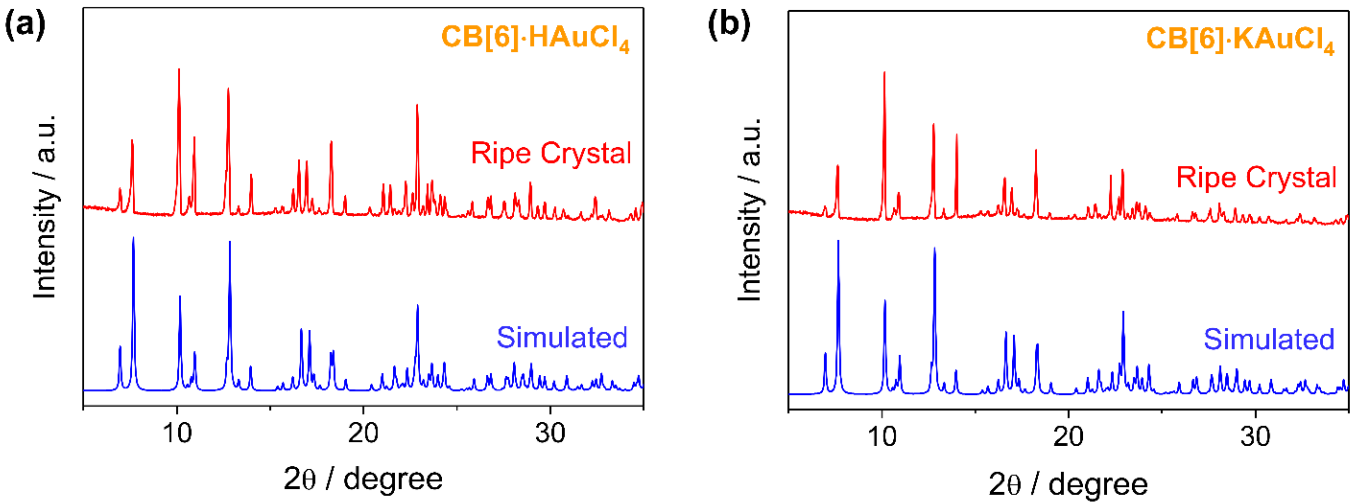

Figure S6. Powder X-ray diffraction patterns for the ripe crystal of (a) $\mathbf{C B}[6] \cdot \mathbf{H A u C l} 4$, (b) $\mathbf{C B}[\mathbf{6}] \cdot \mathbf{K A u C l} 4$, obtained by the co-precipitation of them after standing 3 days, compared with simulated patterns derived from their X-ray crystallographic data. The results reveal that there are no crystalline transformations during the Ostwald ripening process.

\section{Section E. Fourier-Transform Infrared/Thermogravimetric Analysis}

(a)

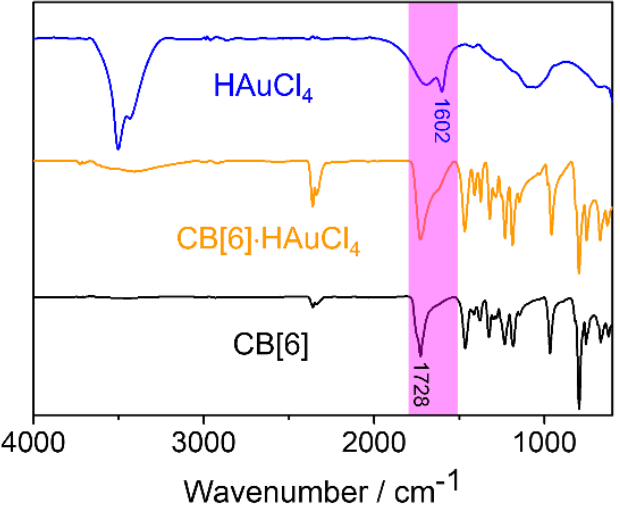

(c)

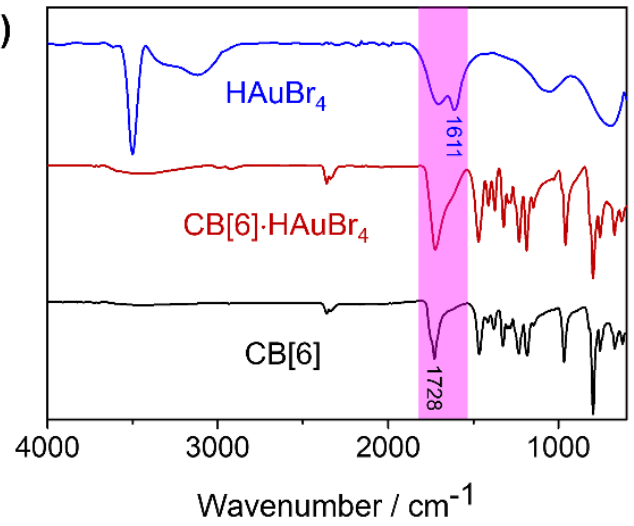

(b)

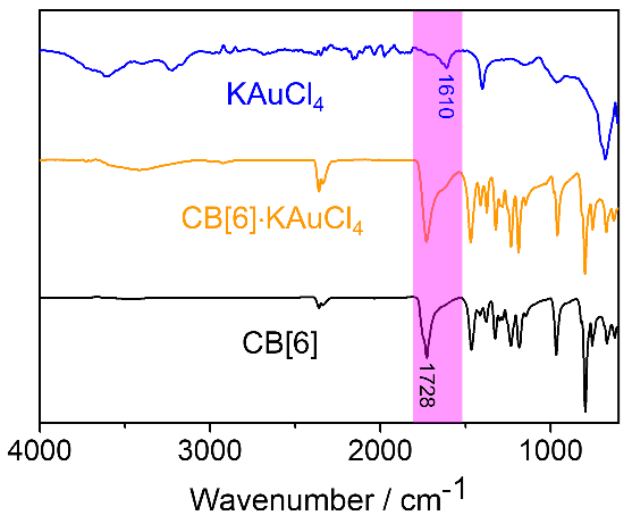

(d)

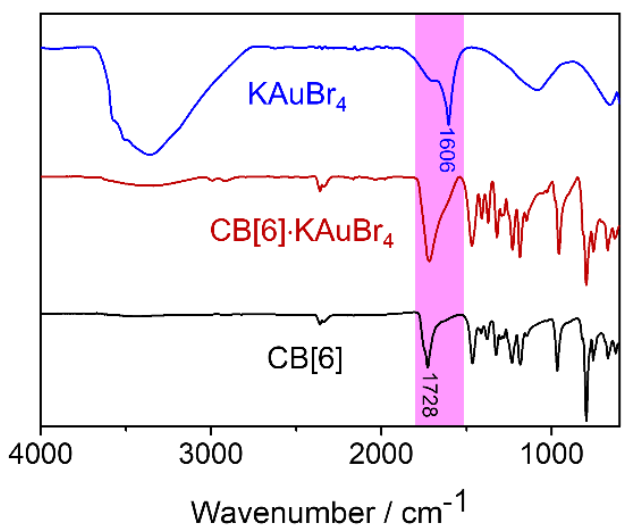

Figure S7. Fourier-transform infrared (FTIR) spectra for the co-precipitates of (a) CB[6]·HAuCl4, (b) $\mathrm{CB}[6] \cdot \mathrm{KAuCl}_{4}$, (c) $\mathrm{CB}[6] \cdot \mathrm{HAuBr}_{4}$, (d) $\mathrm{CB}[6] \cdot \mathrm{KAuBr}_{4}$, compared with the spectra of their corresponding components $\mathrm{CB}[6], \mathrm{HAuCl}_{4}$ hydrate, $\mathrm{KAuCl}_{4}, \mathrm{HAuBr}_{4}$ hydrate and $\mathrm{KAuBr}_{4}$ hydrate, respectively. 


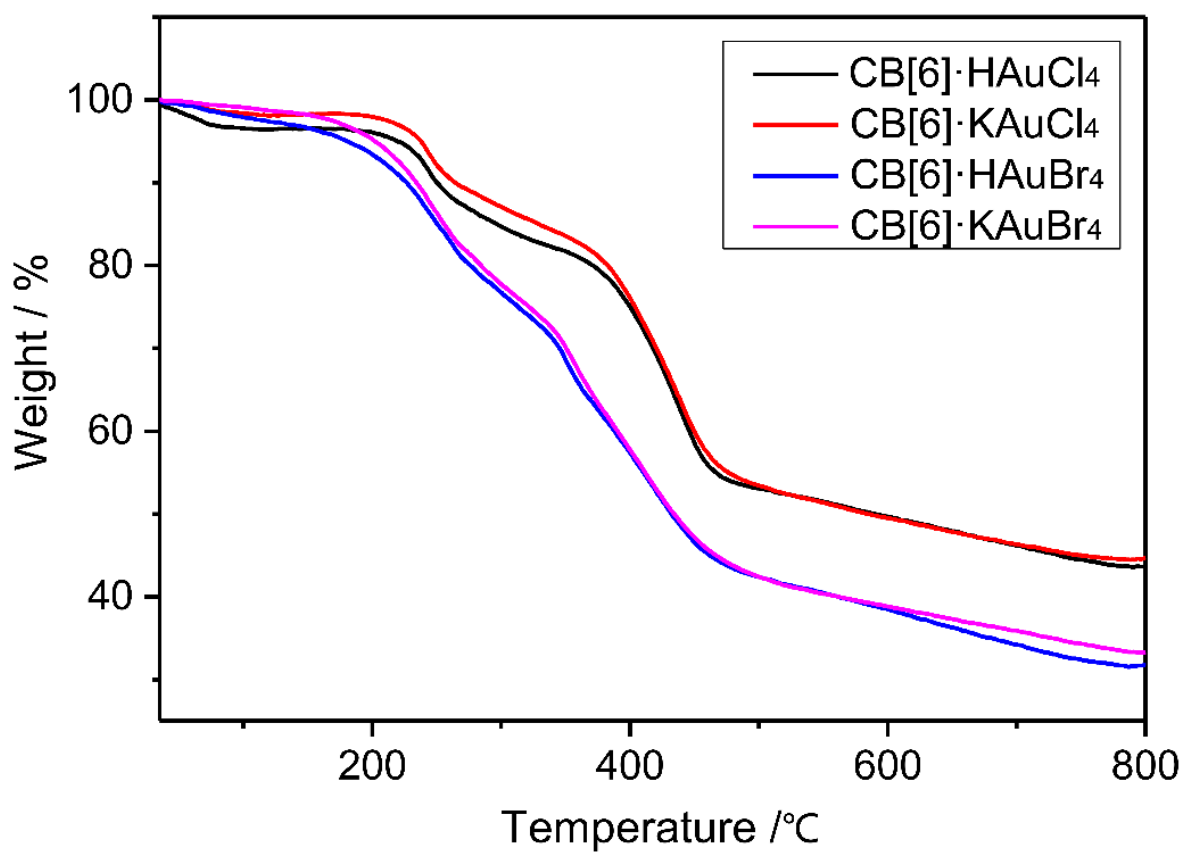

Figure S8. Thermogravimetric analysis (TGA) of the co-precipitates of the four adducts $\mathrm{CB}[6] \cdot \mathrm{HAuCl}_{4}, \mathrm{CB}[6] \cdot \mathrm{KAuCl}_{4}, \mathrm{CB}[6] \cdot \mathrm{HAuBr}_{4}$ and $\mathrm{CB}[6] \cdot \mathrm{KAuBr}_{4}$

\section{Section F. Density Function Theory Calculations}

In order to gain a better understanding of the driving force and bonding energy between $\mathrm{CB}[6]$ and $\left[\mathrm{AuCl}_{4}\right]^{-},\left[\mathrm{AuBr}_{4}\right]^{-}$, as well as the adjacent $\mathrm{CB}[6]$ molecules, DFT calculations have been carried out based on the crystal superstructures of $\mathbf{C B}[\mathbf{6}] \cdot \mathbf{H A u C l}_{\mathbf{4}}$ and $\mathbf{C B}[\mathbf{6}] \cdot \mathbf{H A u B r} 4$. Figures S9-10 show the binding modes of $\mathrm{CB}[6]$ and $\left[\mathrm{AuCl}_{4}\right]^{-}$, as well as those between adjacent $\mathrm{CB}[6]$ molecules in the solid-state superstructure of $\mathbf{C B}[\mathbf{6}] \cdot \mathbf{H A u C l}_{4}$, respectively. Tables $\mathrm{S} 2-3$ summarizes the binding energies between $\mathrm{CB}[6]$ and $\left[\mathrm{AuCl}_{4}\right]^{-}$, as well as those between adjacent $\mathrm{CB}[6]$ molecules, according to DFT calculations, respectively. Figures S11-12 show the binding modes of $\mathrm{CB}[6]$ and $\left[\mathrm{AuBr}_{4}\right]^{-}$, as well as those between adjacent $\mathrm{CB}[6]$ molecules in the solid-state superstructure of $\mathbf{C B}[6] \cdot \mathbf{H A u B r} 4$, respectively. Tables $\mathrm{S} 4-5$ summarizes the binding energies between $\mathrm{CB}[6]$ and $\left[\mathrm{AuBr}_{4}\right]^{-}$, as well as those between adjacent $\mathrm{CB}[6]$ molecules, according to DFT calculations, respectively.

The DFT calculations were performed with the Orca program (version 4.1.0). The hybrid functional Becke three-peramater Lee-Yang-Parr (B3LYP) with Grimme's van der Waals corrections with Beck-Johnson damping (D3BJ) were used. Ahlrich's double zeta basis set with a polarization function (Def2-SVP) and electron-core potentials (Def2-ECPs) were used. The binding energies 
were calculated from $E_{\mathrm{b}}, \mathrm{AB}=E_{\mathrm{total}, \mathrm{A}}-E_{\mathrm{total}, \mathrm{B}}$. The resolution of the identity with Coulomb integral and numerical chain-of-sphere integration for the HF exchange (RIJCOSX) was applied to improve the computational efficiency.

The meanings of physical quantity is recorded in the Tables S2-5 are as follows -

$E_{\mathrm{SCF}}$ is the converged electronic energy.

$E_{\mathrm{vdW}}$ is the van der Waals correction energy.

$E_{\text {total }}$ is the van der Waals -corrected total electronic energy.

$E_{\mathrm{b}}$ is the binding energy (a thermodynamic quantity).

(1) The binding energies between $\mathrm{CB}[6]$ and $\left[\mathrm{AuCl}_{4}\right]^{-}$in the crystal of $\mathrm{CB}[6] \cdot \mathrm{HAuCl}$.

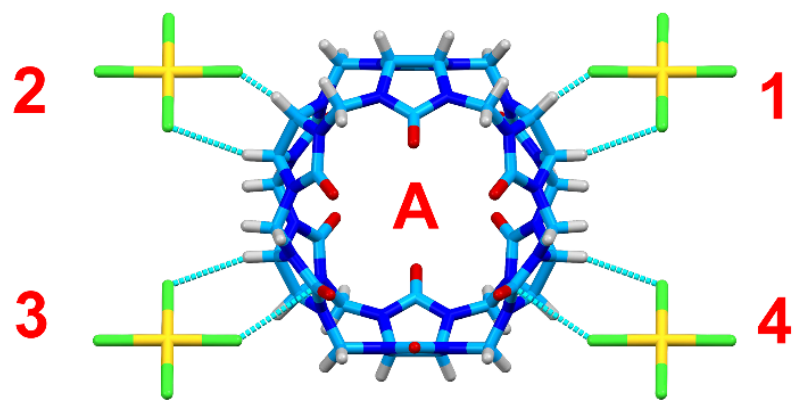

Front View

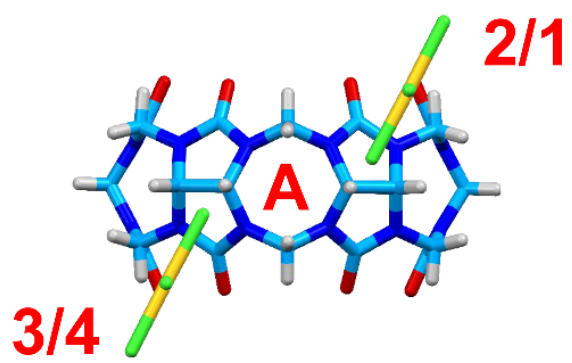

Side-on View

Figure S9. Capped-sticks representations showing the different views of how the CB[6] (A) interacts with four $\left[\mathrm{AuCl}_{4}\right]^{-}$anions (1-4) in the solid-state superstructure of $\mathbf{C B}[\mathbf{6}] \cdot \mathbf{H A u C l} 4$

Table S2. Results of DFT Calculation for the Binding Energies Between CB[6] (A) and the Four Connected $\left[\mathrm{AuCl}_{4}\right]^{-}$Anions (1-4) Based on the Solid-State Superstructure of $\mathrm{CB}[6] \cdot \mathrm{HAuCl}_{4}$

\begin{tabular}{|c|c|c|c|c|c|c|}
\hline Entry & $E_{\text {SCF }} /$ ha & $E_{\text {vdW }} /$ ha & $\boldsymbol{E}_{\text {Total }} /$ ha & $E_{\mathrm{b}} / \mathrm{kcal} \mathrm{mol}^{-1}$ & $E_{b}(\%)$ & Dipole / Debye \\
\hline A-1 & -5581.229 & -0.353 & -5581.582 & 34.828 & 100 & 17.090 \\
\hline A-2 & -5581.229 & -0.353 & -5581.582 & 34.829 & 100 & 17.084 \\
\hline A-3 & -5581.229 & -0.353 & -5581.582 & 34.829 & 100 & 17.086 \\
\hline A-4 & -5581.229 & -0.353 & -5581.582 & 34.829 & 100 & 17.082 \\
\hline
\end{tabular}

$\mathrm{A}-\mathrm{X}(\mathrm{X}=1-4)$ represent two interacting molecules named in Figure 9. 
(2) The binding energies between interactional $\mathrm{CB}[6]$ in the crystal of $\mathrm{CB}[6] \cdot \mathrm{HAuCl} 4$.

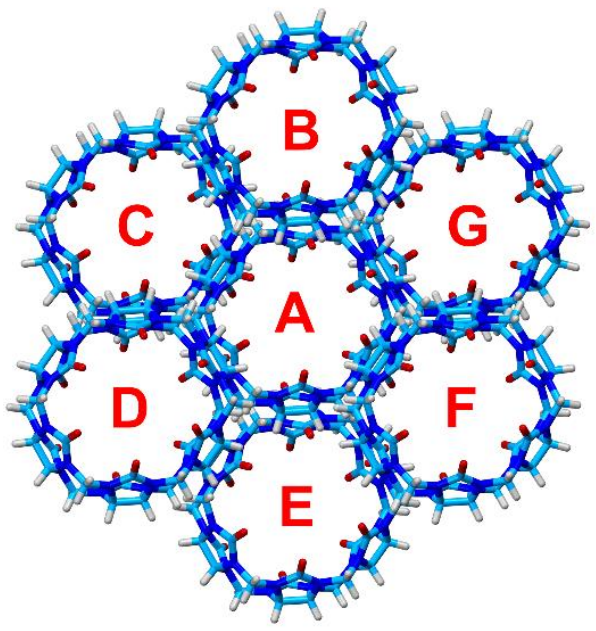

Front View

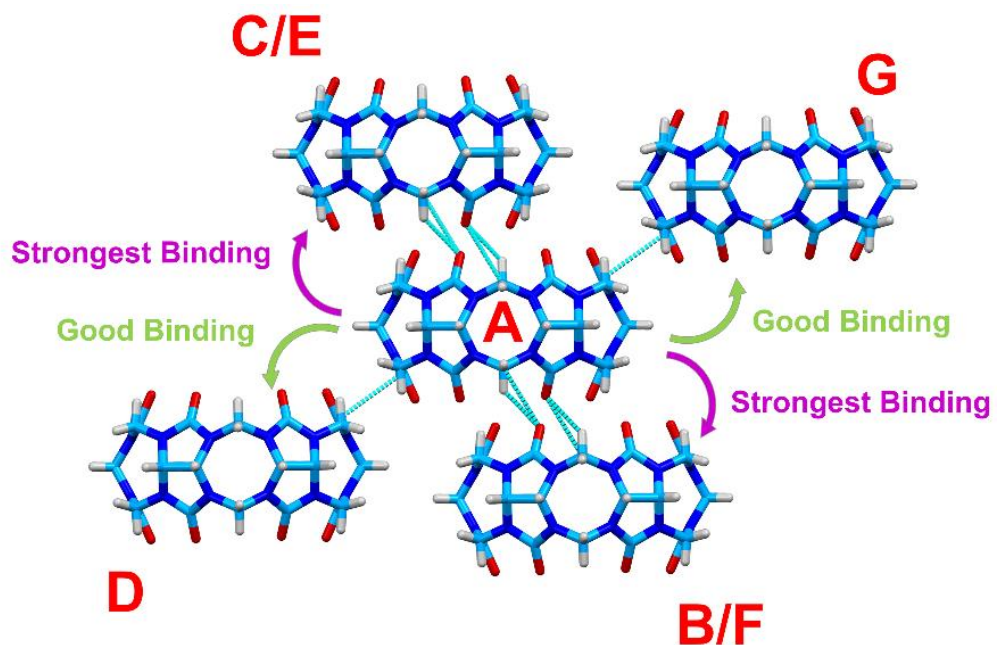

Side-on View

Figure S10. Capped-stick representations showing the different views of how the centrally located $\mathrm{CB}[6]$ (A) interacts with six adjacent $\mathrm{CB}[6]$ molecules $(\mathrm{B}-\mathrm{G})$ in the solid-state superstructure of $\mathrm{CB}[6] \cdot \mathrm{HAuCl}_{4}$

Table S3. Results of DFT Calculation for the Binding Energies Between CB[6] (A) and the Six Connected CB[6] (B-G) Based on the Solid-State Superstructure of CB[6]·HAuCl 4

\begin{tabular}{|c|c|c|c|c|c|c|}
\hline Entry & $E_{\text {SCF }} /$ ha & $E_{\text {vdW } / \text { ha }}$ & $E_{\text {Total }} /$ ha & $E_{\mathrm{b}} / \mathrm{kcal} \mathrm{mol}^{-1}$ & $E_{b}(\%)$ & Dipole / Debye \\
\hline $\mathbf{A}-\mathbf{B}$ & -7211.018 & -0.661 & -7211.679 & 26.028 & 100 & 0.00019 \\
\hline$A-C$ & -7211.018 & -0.661 & -7211.679 & 26.028 & 100 & 0.00021 \\
\hline A-D & -7211.009 & -0.665 & -7211.673 & 22.622 & 87 & 0.00005 \\
\hline $\mathbf{A}-\mathbf{E}$ & -7211.018 & -0.661 & -7211.679 & 26.028 & 100 & 0.00025 \\
\hline $\mathbf{A}-\mathbf{F}$ & -7211.018 & -0.661 & -7211.679 & 26.028 & 100 & 0.00026 \\
\hline $\mathbf{A}-\mathbf{G}$ & -7211.009 & -0.665 & -7211.673 & 22.622 & 87 & 0.00029 \\
\hline
\end{tabular}

$\mathrm{A}-\mathrm{X}(\mathrm{X}=\mathrm{B}-\mathrm{G})$ represent two interacting molecules named in Figure 10. 
(3) The binding energies between $\mathrm{CB}[6]$ and $\left[\mathrm{AuBr}_{4}\right]^{-}$in crystal structure of $\mathrm{CB}[6] \cdot \mathrm{HAuBr} 4$.

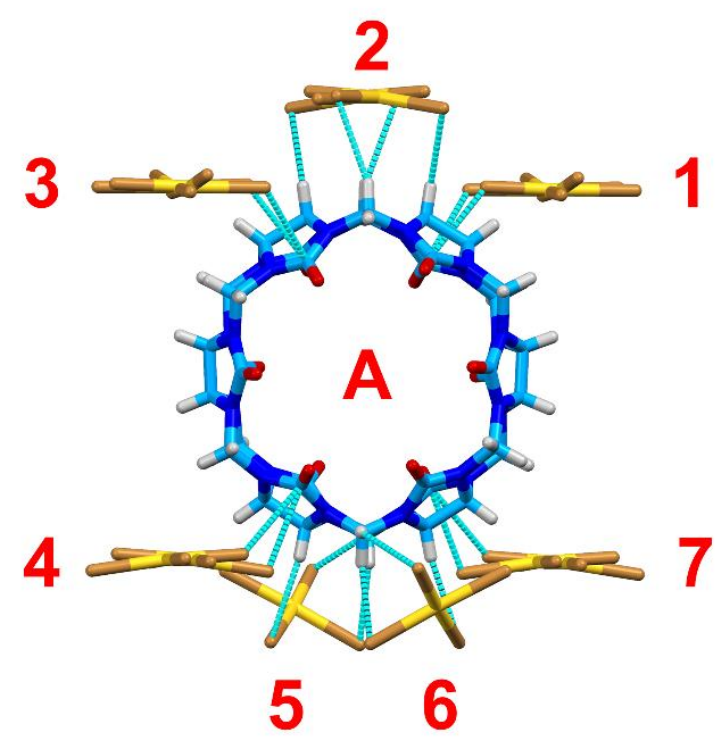

Front View

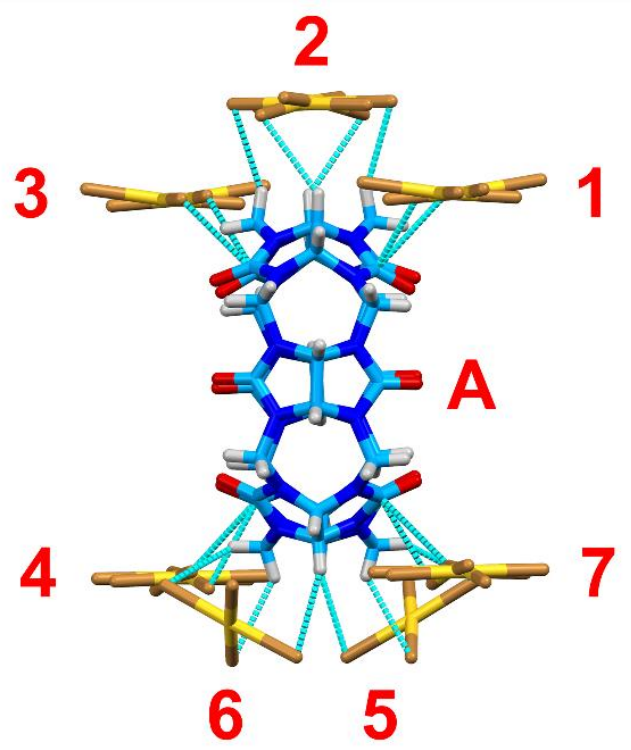

Side-on View

Figure S11. Capped-stick representations showing the different views of how the CB[6] (A) interacts with seven $\left[\mathrm{AuBr}_{4}\right]^{-}$anions (1-7) in the solid-state superstructure of $\mathbf{C B}[\mathbf{6}] \cdot \mathbf{H A u B r} 4$

Table S4. Results of DFT Calculation for the Binding Energies Between CB[6] (A) and the Seven Connected [AuBr4 $]^{-}$Anions (1-7) Based on the Solid-State Superstructure of $\mathrm{CB}[6] \cdot \mathrm{HAuBr} 4$

\begin{tabular}{|c|c|c|c|c|c|c|}
\hline Entry & $E_{\text {SCF }} /$ ha & $E_{\text {vdw / ha }}$ & $\boldsymbol{E}_{\text {Total }} /$ ha & $E_{\mathrm{b}} / \mathrm{kcal} \mathrm{mol}^{-1}$ & $E_{\mathrm{b}}(\%)$ & Dipole / Debye \\
\hline A-1 & -14036.109 & -0.358 & -14036.467 & 11.260 & 36 & 10.335 \\
\hline A-2 & -14036.118 & -0.364 & -14036.483 & 21.278 & 68 & 13.960 \\
\hline A-3 & -14036.109 & -0.358 & -14036.467 & 11.234 & 36 & 10.329 \\
\hline A-4 & -14036.110 & -0.361 & -14036.471 & 13.832 & 44 & 10.068 \\
\hline A-5 & -14036.109 & -0.370 & -14036.479 & 31.252 & 100 & 10.321 \\
\hline A-6 & -14036.109 & -0.370 & -14036.479 & 31.266 & 100 & 10.379 \\
\hline A-7 & -14036.110 & -0.361 & -14036.471 & 13.832 & 44 & 10.070 \\
\hline
\end{tabular}


(4) The binding energies between interactional $\mathrm{CB}[6]$ in crystal structure of $\mathrm{CB}[6] \cdot \mathrm{HAuBr}$.

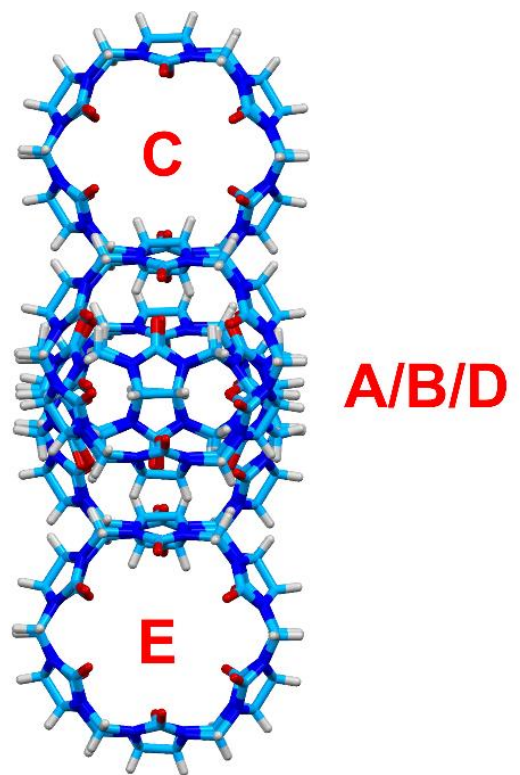

Front View

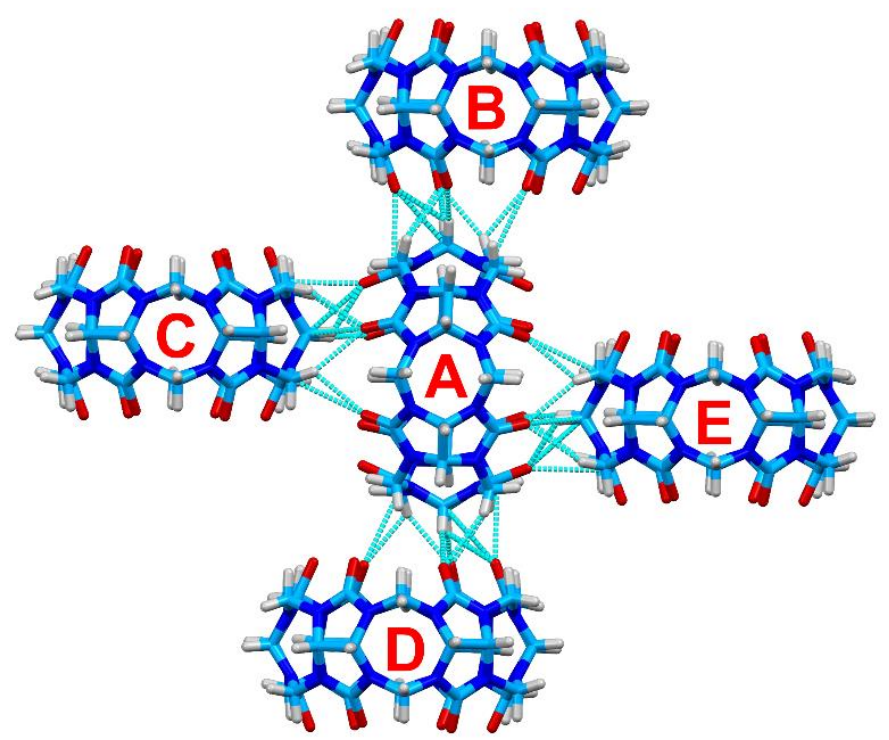

Side-on View

Figure S12. Capped-stick representations showing the different views of how the centrally located $\mathrm{CB}[6]$ (A) interacts with four adjacent $\mathrm{CB}[6]$ molecules $(\mathrm{B}-\mathrm{E})$ in the solid-state superstructure of CB[6]·HAuBr4

Table S5. Results of DFT Calculation for the Binding Energies Between CB[6] (A) and Four Connected CB[6] (B-E) Based on the Solid-State Superstructure of CB[6]·HAuBr4

Entry $E_{\mathrm{SCF}} / \mathrm{ha} \quad E_{\mathrm{vdW}} / \mathrm{ha} \quad E_{\text {Total }} / \mathrm{ha} \quad E_{\mathrm{b}} / \mathrm{kcal} \mathrm{mol}^{-1} E_{\mathrm{b}}(\%)$ Dipole / Debye

$\begin{array}{lllllll}\text { A-B } & -3605.433 & -0.324 & -3605.757 & 39.481 & 100 & 7.976\end{array}$

$\begin{array}{lllllll}\text { A-C } & -7210.866 & -0.648 & -7211.515 & 39.479 & 100 & 7.975\end{array}$

$\begin{array}{lllllll}\text { A-D } & -3605.433 & -0.324 & -3605.757 & 39.481 & 100 & 7.976\end{array}$

$\begin{array}{lllllll}\mathbf{A}-\mathbf{E} & -7210.866 & -0.648 & -7211.515 & 39.479 & 100 & 7.975\end{array}$

$\mathrm{A}-\mathrm{X}(\mathrm{X}=\mathrm{B}-\mathrm{E})$ represent two interacting molecules named in Figure 12. 


\section{Section G. ICP-OES Analysis}

(1) Calibration graphs for ICP-OES for Au element analysis
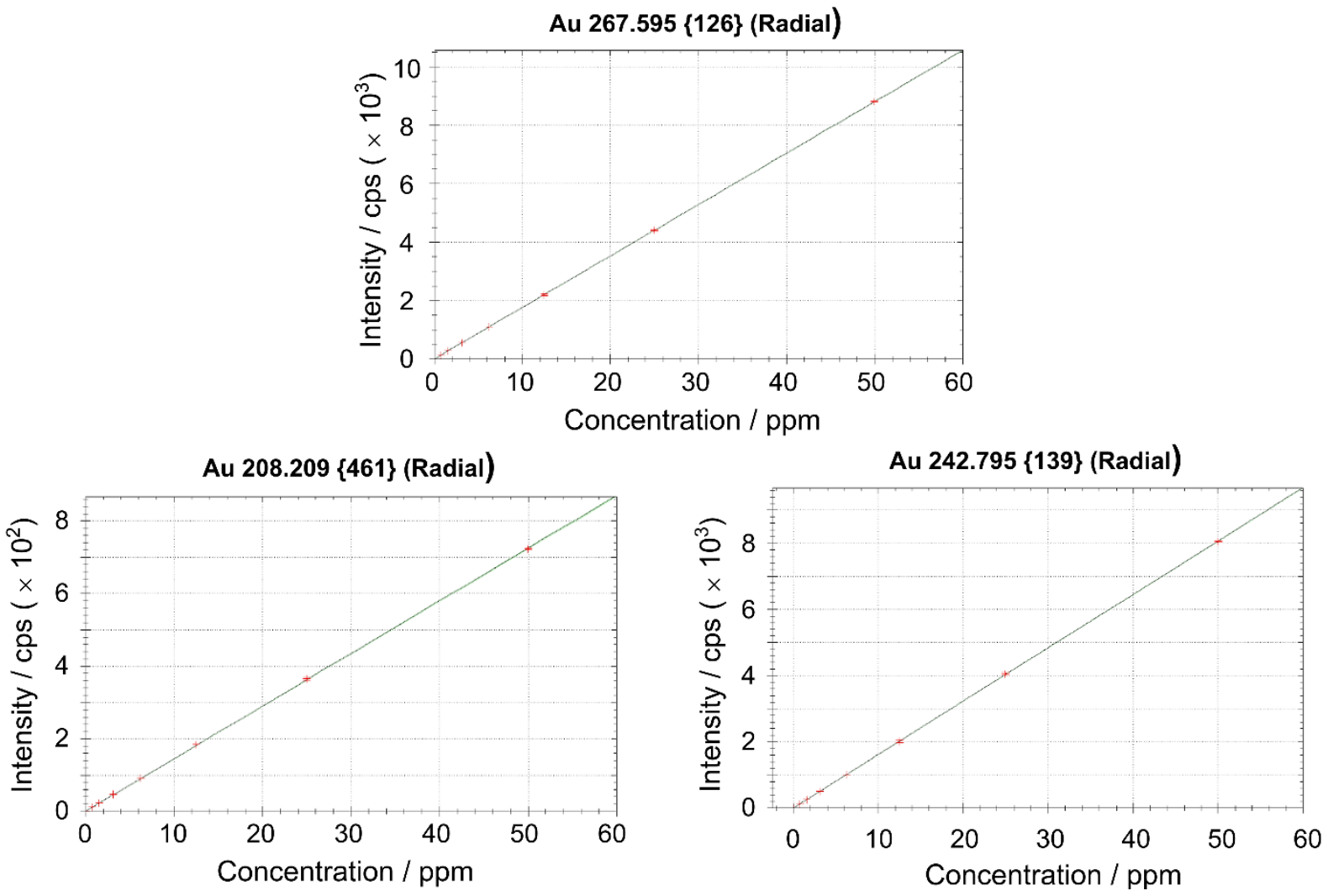

Figure S13. Calibration graphs for ICP-OES for Au element analysis recorded over a range of concentrations from 0.78 to $50 \mathrm{ppm}$ in $2 \% \mathrm{HCl}$ and $\mathrm{HNO}_{3}$ aqueous solutions, $R^{2}=0.9999$.

(2) Gold-recovery efficiencies for the four co-precipitates between $\mathrm{CB}[6]$ and $\mathrm{HAuCl}_{4}$, KAuCl4, HAuBr4, KAuBr4.

Table S6. The Gold-Recovery Efficiencies for the Four Co-Precipitates of CB[6]•MAuX4 (M $=\mathrm{H} / \mathrm{K}, \mathrm{X}=\mathrm{Cl} / \mathrm{Br}$ )

\begin{tabular}{|c|c|c|c|c|c|c|c|}
\hline & $\begin{array}{l}\text { p7.595 } \\
\text { ppm }\end{array}$ & $\begin{array}{c}\text { Au } 208.209 \\
\quad / \text { ppm }\end{array}$ & $\begin{array}{c}\text { Au } 242.795 \\
\text { / ppm }\end{array}$ & $\begin{array}{l}\text { Avg. Au } \\
\text { / ppm }\end{array}$ & $\begin{array}{c}\text { Au in } \\
\text { Filtrate / mg }\end{array}$ & $\begin{array}{c}\text { Total Au } \\
\text { / mg }\end{array}$ & $\begin{array}{l}\text { Recovery } \\
\text { Efficiency }\end{array}$ \\
\hline $\mathrm{CB}[6] \cdot \mathrm{HAuCl}_{4}$ & 0.970 & 1.002 & 1.046 & 1.006 & 0.023 & 0.591 & 0.962 \\
\hline $\mathrm{CB}[6] \cdot \mathrm{KAuCl}_{4}$ & 1.299 & 1.320 & 1.651 & 1.423 & 0.032 & 0.591 & 0.946 \\
\hline $\mathrm{CB}[6] \cdot \mathrm{HAuBr} 4$ & 1.412 & 1.403 & 1.630 & 1.482 & 0.039 & 0.591 & 0.934 \\
\hline $\mathrm{CB}[6] \cdot \mathrm{KAuBr} 4$ & 1.410 & 1.419 & 1.633 & 1.487 & 0.039 & 0.591 & 0.934 \\
\hline
\end{tabular}


(3) Effect of changes in concentration of $\mathrm{CB}[6] \cdot \mathrm{MAuX} 4$ on the gold-recovery efficiency.

Table S7. The Gold-Recovery Efficiency Changes with the Concentration of $\mathrm{CB}[6] \cdot \mathrm{HAuCl}_{4}$ in $2 \mathrm{M} \mathrm{HCl} \mathrm{Aqueous} \mathrm{Solutions}$

\begin{tabular}{|c|c|c|c|c|c|c|c|}
\hline $\begin{array}{c}\text { Concentration of } \\
\mathrm{CB}[6] \cdot \mathrm{HAuCl}_{4} / \mathrm{mM}\end{array}$ & $\begin{array}{c}\text { Au } 267.595 \\
\text { / ppm }\end{array}$ & $\begin{array}{c}\text { Au } 208.209 \\
\text { / ppm }\end{array}$ & $\begin{array}{c}\text { Au } 242.795 \\
\qquad / \text { ppm }\end{array}$ & $\begin{array}{l}\text { Avg. Au } \\
\text { / ppm }\end{array}$ & $\begin{array}{c}\text { Au in } \\
\text { Filtrate / mg }\end{array}$ & $\begin{array}{c}\text { Total Au } \\
\text { / mg }\end{array}$ & $\begin{array}{l}\text { Recovery } \\
\text { Efficiency }\end{array}$ \\
\hline 10.0 & 0.319 & 0.308 & 0.305 & 0.310 & 0.009 & 1.182 & 0.992 \\
\hline 8.0 & 0.377 & 0.381 & 0.372 & 0.377 & 0.014 & 1.182 & 0.988 \\
\hline 6.0 & 0.416 & 0.411 & 0.410 & 0.413 & 0.010 & 0.591 & 0.982 \\
\hline 4.0 & 1.147 & 1.125 & 1.144 & 1.139 & 0.043 & 0.591 & 0.928 \\
\hline 2.0 & 3.970 & 3.925 & 3.953 & 3.949 & 0.296 & 0.591 & 0.499 \\
\hline 0.5 & 1.812 & 1.792 & 1.815 & 1.806 & 0.072 & 0.079 & 0.083 \\
\hline
\end{tabular}

Table S8. The Gold-Recovery Efficiency Changes with the Concentration of $\mathrm{CB}[6] \cdot \mathrm{KAuCl}_{4}$ in $2 \mathrm{M} \mathrm{HCl}$ Aqueous Solutions

\begin{tabular}{|c|c|c|c|c|c|c|c|}
\hline $\begin{array}{c}\text { Concentration of } \\
\mathrm{CB}[6] \cdot \mathrm{KAuCl}_{4} / \mathrm{mM}\end{array}$ & $\begin{array}{c}\text { Au } 267.59 \\
/ \text { ppm }\end{array}$ & $\begin{array}{c}\text { Au } 208.209 \\
\text { / ppm }\end{array}$ & $\begin{array}{c}\text { Au } 242.795 \\
\quad / \text { ppm }\end{array}$ & $\begin{array}{c}\text { Avg. Au } \\
\text { / ppm }\end{array}$ & $\begin{array}{c}\text { Au in } \\
\text { Filtrate / mg }\end{array}$ & $\begin{array}{c}\text { Total Au } \\
\text { / mg }\end{array}$ & $\begin{array}{l}\text { Recovery } \\
\text { Efficiency }\end{array}$ \\
\hline 10.0 & 0.331 & 0.287 & 0.329 & 0.316 & 0.009 & 1.182 & 0.992 \\
\hline 8.0 & 0.471 & 0.475 & 0.454 & 0.467 & 0.018 & 1.182 & 0.985 \\
\hline 6.0 & 0.548 & 0.529 & 0.539 & 0.539 & 0.013 & 0.591 & 0.977 \\
\hline 4.0 & 1.056 & 1.029 & 1.029 & 1.038 & 0.039 & 0.591 & 0.934 \\
\hline 2.0 & 3.571 & 3.559 & 3.524 & 3.551 & 0.266 & 0.591 & 0.549 \\
\hline 0.5 & 1.814 & 1.763 & 1.812 & 1.796 & 0.072 & 0.079 & 0.088 \\
\hline
\end{tabular}


Table S9. The Gold-Recovery Efficiency Changes with the Concentration of $\mathrm{CB}[6] \cdot \mathrm{HAuBr} 4$ in 2.5 M HBr Aqueous Solutions

\begin{tabular}{|c|c|c|c|c|c|c|c|}
\hline $\begin{array}{c}\text { Concentration of } \\
\mathrm{CB}[6] \cdot \mathrm{HAuBr}_{4} / \mathrm{mM}\end{array}$ & $\begin{array}{c}\text { Au } 267.595 \\
\quad / \text { ppm }\end{array}$ & $\begin{array}{l}208.209 \\
/ \mathrm{ppm}\end{array}$ & $\begin{array}{l}242.795 \\
/ \mathrm{ppm}\end{array}$ & $\begin{array}{l}\text { Avg. Au } \\
\text { / ppm }\end{array}$ & $\begin{array}{c}\text { Au in } \\
\text { Filtrate / mg }\end{array}$ & $\begin{array}{c}\text { Total Au } \\
\text { / mg }\end{array}$ & $\begin{array}{l}\text { Recovery } \\
\text { Efficiency }\end{array}$ \\
\hline 5.7 & 1.412 & 1.403 & 1.630 & 1.482 & 0.039 & 0.591 & 0.934 \\
\hline 4.0 & 1.866 & 1.905 & 1.861 & 1.877 & 0.070 & 0.591 & 0.881 \\
\hline 2.0 & 2.144 & 2.170 & 2.137 & 2.150 & 0.161 & 0.591 & 0.727 \\
\hline 1.2 & 2.277 & 2.308 & 2.452 & 2.345 & 0.195 & 0.394 & 0.504 \\
\hline 0.5 & 1.564 & 1.555 & 1.567 & 1.562 & 0.047 & 0.059 & 0.207 \\
\hline
\end{tabular}

Table S10. The Gold-Recovery Efficiency Changes with the Concentration of $\mathrm{CB}[6] \cdot \mathrm{KAuBr}_{4}$ in 2.5 M HBr Aqueous Solutions

\begin{tabular}{|c|c|c|c|c|c|c|c|}
\hline $\begin{array}{c}\text { Concentration of } \\
\mathrm{CB}[6] \cdot \mathrm{KAuBr}_{4} / \mathrm{mM}\end{array}$ & $\begin{array}{c}\text { Au } 267.595 \\
\quad / \text { ppm }\end{array}$ & $\begin{array}{c}\text { Au } 208.209 \\
\quad / \text { ppm }\end{array}$ & $\begin{array}{c}\text { Au } 242.795 \\
/ \text { ppm }\end{array}$ & $\begin{array}{l}\text { Avg. Au } \\
\text { / ppm }\end{array}$ & $\begin{array}{c}\text { Au in } \\
\text { Filtrate / mg }\end{array}$ & $\begin{array}{c}\text { Total Au } \\
\text { / mg }\end{array}$ & $\begin{array}{l}\text { Recovery } \\
\text { Efficiency }\end{array}$ \\
\hline 5.7 & 1.410 & 1.419 & 1.633 & 1.487 & 0.039 & 0.591 & 0.934 \\
\hline 4.0 & 1.846 & 1.865 & 1.846 & 1.852 & 0.069 & 0.591 & 0.882 \\
\hline 2.0 & 2.138 & 2.152 & 2.132 & 2.141 & 0.161 & 0.591 & 0.728 \\
\hline 1.2 & 2.345 & 2.373 & 2.459 & 2.392 & 0.200 & 0.394 & 0.493 \\
\hline 0.5 & 1.718 & 1.751 & 1.718 & 1.729 & 0.052 & 0.059 & 0.122 \\
\hline
\end{tabular}


(4) Effect of changes in concentration of $\mathrm{HCl}$ on the gold-recovery efficiency based on $\mathrm{CB}[6] \cdot \mathrm{MAuCl}_{4}(\mathrm{M}=\mathrm{H} / \mathrm{K})$.

Table S11. The Gold-Recovery Efficiency Changes with the Concentration of HCl, When the Concentrations of $\mathrm{CB}[6]$ and $\mathrm{HAuCl}_{4}$ in All the Aqueous Solutions are $6 \mathrm{mM}$

\begin{tabular}{|c|c|c|c|c|c|c|c|}
\hline $\begin{array}{c}\text { Concentration o } \\
\qquad \mathrm{HCl} / \mathrm{M}\end{array}$ & $\begin{array}{c}\text { Au } 267.595 \\
\text { / ppm }\end{array}$ & $\begin{array}{c}\text { Au } 208.209 \\
\text { / ppm }\end{array}$ & $\begin{array}{l}\text { Au } 242.795 \\
\quad / \text { ppm }\end{array}$ & $\begin{array}{l}\text { Avg. Au } \\
\text { / ppm }\end{array}$ & $\begin{array}{c}\text { Au in } \\
\text { Filtrate / mg }\end{array}$ & $\begin{array}{c}\text { Total Au } \\
\text { / mg }\end{array}$ & $\begin{array}{l}\text { Recovery } \\
\text { Efficiency }\end{array}$ \\
\hline 10.0 & 22.700 & 22.571 & 23.290 & 22.854 & 0.571 & 0.591 & 0.033 \\
\hline 8.0 & 19.995 & 19.822 & 20.464 & 20.094 & 0.502 & 0.591 & 0.150 \\
\hline 6.0 & 16.117 & 16.049 & 16.571 & 16.246 & 0.406 & 0.591 & 0.313 \\
\hline 4.0 & 6.781 & 6.938 & 6.900 & 6.873 & 0.172 & 0.591 & 0.709 \\
\hline 2.0 & 0.829 & 0.865 & 0.861 & 0.852 & 0.021 & 0.591 & 0.964 \\
\hline 1.0 & 2.702 & 2.777 & 2.754 & 2.744 & 0.069 & 0.591 & 0.884 \\
\hline
\end{tabular}

Table S12. The Gold-Recovery Efficiency Changes with the Concentration of HCl, When the Concentrations of $\mathrm{CB}[6]$ and $\mathrm{KAuCl}_{4}$ in All the Aqueous Solutions are $6 \mathrm{mM}$

\begin{tabular}{|c|c|c|c|c|c|c|c|}
\hline $\begin{array}{c}\text { Concentration of } \\
\qquad \mathrm{HCl} / \mathrm{M}\end{array}$ & $\begin{array}{c}\text { Au } 267.595 \\
\text { / ppm }\end{array}$ & $\begin{array}{c}\text { Au } 208.209 \\
\quad / \text { ppm }\end{array}$ & $\begin{array}{c}\text { Au } 242.795 \\
\quad / \text { ppm }\end{array}$ & $\begin{array}{c}\text { Avg. Au } \\
\text { / ppm }\end{array}$ & $\begin{array}{c}\text { Au in } \\
\text { Filtrate / mg }\end{array}$ & $\begin{array}{c}\text { Total Au } \\
\text { / mg }\end{array}$ & $\begin{array}{l}\text { Recovery } \\
\text { Efficiency }\end{array}$ \\
\hline 10.0 & 22.083 & 21.843 & 23.144 & 22.357 & 0.559 & 0.591 & 0.054 \\
\hline 8.0 & 21.544 & 21.330 & 22.516 & 21.797 & 0.545 & 0.591 & 0.078 \\
\hline 6.0 & 16.815 & 16.626 & 17.546 & 16.996 & 0.425 & 0.591 & 0.281 \\
\hline 4.0 & 7.750 & 7.674 & 8.077 & 7.834 & 0.196 & 0.591 & 0.669 \\
\hline 2.0 & 0.628 & 0.878 & 0.689 & 0.732 & 0.018 & 0.591 & 0.969 \\
\hline 1.0 & 3.233 & 3.268 & 3.398 & 3.299 & 0.082 & 0.591 & 0.860 \\
\hline
\end{tabular}


(5) The laboratory-scale gold-recovery form gold alloy.

Table S13. The Gold-Recovery Efficiency from Gold Alloy Based on the Co-precipitate of $\mathrm{CB}[6] \cdot \mathrm{HAuCl}_{4}$

\begin{tabular}{cccccccc}
\hline & $\begin{array}{c}\text { Au 267.595 } \\
\text { / ppm }\end{array}$ & $\begin{array}{c}\text { Au 208.209 } \\
\text { / ppm }\end{array}$ & $\begin{array}{c}\text { Au 242.795 } \\
\text { / ppm }\end{array}$ & $\begin{array}{c}\text { Avg. Au } \\
\text { / ppm }\end{array}$ & $\begin{array}{c}\text { Au in } \\
\text { Filtrate / mg }\end{array}$ & $\begin{array}{c}\text { Total Au } \\
\text { / mg }\end{array}$ & $\begin{array}{c}\text { Recovery } \\
\text { Efficiency }\end{array}$ \\
\hline CB[6]·Au Alloy & 0.168 & 0.157 & 0.184 & 0.170 & 0.005 & 2.403 & 0.998 \\
\hline
\end{tabular}

Table S14. The Purity of Recovered Gold

\begin{tabular}{cccccccc}
\hline & $\begin{array}{c}\text { Au 267.595 } \\
\text { / ppm }\end{array}$ & $\begin{array}{c}\text { Au 208.209 } \\
\text { / ppm }\end{array}$ & $\begin{array}{c}\text { Au 242.795 } \\
\text { / ppm }\end{array}$ & $\begin{array}{c}\text { Avg. Au } \\
\text { / ppm }\end{array}$ & $\begin{array}{c}\text { Au in } \\
\text { solution / mg }\end{array}$ & $\begin{array}{c}\text { Recovered Au } \\
\text { / mg }\end{array}$ & Purity \\
\hline $\begin{array}{c}\text { Recovered } \\
\text { Gold }\end{array}$ & 0.234 & 0.234 & 0.243 & 0.237 & 1.423 & 1.450 & 0.981 \\
\hline
\end{tabular}

Table S15. The Gold-Recovery Efficiency from 5.5\% wt Au and 2.6\% wt Au Mixture Aqueous Solution Based on the Co-precipitate of $\mathrm{CB}[6] \cdot \mathrm{HAuCl}_{4}$

\begin{tabular}{cccccccc}
\hline & $\begin{array}{c}\text { Au 267.595 } \\
\text { / } \mathbf{~ p p m}\end{array}$ & $\begin{array}{c}\text { Au 208.209 } \\
\text { / } \mathbf{~ p p m ~}\end{array}$ & $\begin{array}{c}\text { Au 242.795 } \\
/ \mathbf{p p m}\end{array}$ & $\begin{array}{c}\text { Avg. Au } \\
/ \mathbf{p p m}\end{array}$ & $\begin{array}{c}\text { Au in } \\
\text { Filtrate / mg }\end{array}$ & $\begin{array}{c}\text { Total Au } \\
/ \mathbf{m g}\end{array}$ & $\begin{array}{c}\text { Recovery } \\
\text { Efficiency }\end{array}$ \\
\hline $\begin{array}{c}\mathbf{5 . 5 \%} \text { wt·Au } \\
\text { Mixture }\end{array}$ & 1.023 & 1.008 & 1.027 & 1.019 & 0.036 & 2.364 & 0.985 \\
$\begin{array}{c}\mathbf{2 . 6 \%} \text { wt·Au } \\
\text { Mixture }\end{array}$ & 1.774 & 1.662 & 1.750 & 1.729 & 0.061 & 2.364 & 0.974 \\
\hline
\end{tabular}

\section{Section H. References}

(1) (a) Kim, J.; Jung, I. S.; Kim, S. Y.; Lee, E.; Kang, J. K.; Sakamoto, S.; Yamaguchi, K.; Kim, K. New Cucurbituril Homologues: Syntheses, Isolation, Characterization, and X-Ray Crystal Structures of Cucurbit[n] uril ( $\mathrm{n}=5$, 7, and 8). J. Am. Chem. Soc. 2000, 122, 540-541. (b) Day, A.; Arnold, A. P.; Blanch, R. J.; Snushall, B. Controlling Factors in the Synthesis of Cucurbituril and Its Homologues. J. Org. Chem. 2001, 66, 8094-8100.

(2) Dolomanov, O. V.; Bourhis, L. J.; Gildea, R. J.; Howard, J. A. K.; Puschmann, H. OLEX2: A Complete Structure Solution, Refinement and Analysis Program. J. Appl. Cryst. 2009, 42, 339-341.

(3) Sheldrick, G. M. SHELXT-Integrated Space-Group and Crystal-Structure Determination. Acta. Cryst. 2015, A71, 3-8.

(4) Sheldrick, G. M. A Short History of SHELX. Acta Cryst 2008, A64, 112-122.

(5) Thorn, A. Dittrich, B. Sheldrick, G. M. Enhanced Rigid-Bond Restraints. Acta. Cryst. 2012, A68, 448-451. 